\title{
Analysis of different factors contributing the rodent infestations in urban areas in Faisalabad, Pakistan
}

\author{
Azhar Rafique ${ }^{1, *}$, M. Shahid Mahmood ${ }^{2}$, Rao Zahid Abbas ${ }^{3}$, Asma Ashraf ${ }^{1}$, Shabab Nasir ${ }^{1}$, Farhat \\ Jabeen ${ }^{1}$, Tayyaba Sultana ${ }^{1}$, Salma Sultana ${ }^{1}$, Ghazanfer Abbas ${ }^{2}$, M. Luqman ${ }^{2}$ 'Ali Abbas ${ }^{4}$, and Shaymaa \\ Fadhel Abbas Albaayit ${ }^{5}$
}
${ }^{1}$ Department of Zoology, GC University Faisalabad, Pakistan; ${ }^{2}$ Institute of Microbiology, University of Agriculture, Faisalabad, Pakistan; ${ }^{3}$ Department of Parasitology, University of Agriculture, Faisalabad, Pakistan; ${ }^{4}$ Veterinary Research Institute Lahore, Pakistan; ${ }^{5}$ Department of Biology, College of Science, University of Baghdad, Baghdad, Iraq
${ }^{*}$ Corresponding author's e-mail: azharrafique96@gmail.com

\begin{abstract}
In the last decade there is a huge increase in the human population that has witnessed the important changes in the ecology, climate and human behaviour which ultimately favours the survival and increase in the population of urban pests. More alarmingly, a dramatic expansion in the rodent's populations is a growing threat to the humans living in different urban settings. It is supposed that several socio-economic issues, environmental factors and type of housing facilities are contributing towards this higher increase in the rodent's population in these areas. However, urban rat control programs are still ineffective as very little is known about their ecology. This study sought to investigate the type of housing and environment factors that provide food, water, shelter and harborage to rats and mice and risk factors of rodent infestations in three of the housing systems i.e. in squatter's settlements, departmental colonies and posh residences including bungalows in Faisalabad. A total of 720 structures (240 each) were selected from these three housing systems. Snap and live trapping of commensal rats and mice (Rattus rattus, Rattus norvegicus, Mus musculus) was carried out fortnightly from November, 2017 to October, 2018 suspecting the rats and mice population as variable as different structured housing systems. The removal data were used to estimate the size of the population of rats and mice per system. For rat and mice population estimation, Change-in-ratio (CIR) and Regression of daily capture on cumulative captures (RR) were employed. The higher number of rats/mice (814 specimens) were collected in squatter' settlements. Among these 560, 184 and 70 specimens were of Mus musculus, Rattus rattus and Suncus murinus, respectively. The number of rodents captured from departmental colonies and posh residences/bungalows was 210 specimens (129 of M. musculus, 71 of $R$. rattus and 10 specimens of $S$. murinus) and 30 specimens of M. musculus, respectively. The major socio-economic factors contributing to these higher rodent infestations were low-grade residences with inadequate or no building maintenance measures and higher housing densities along with heterogenous breeding sites. These higher densities of rats and mice may pose a serious disease threats to human populations as they are carriers of a number of pathogens. The findings of the present study provide the specific features of rats and mice population in concern to human residences and may help to formulate controlling strategies against these culprits.
\end{abstract}

Keywords: Mus musculus, rattus, squatter settlements, Socio-economic factors.

\section{INTRODUCTION}

With the sole exception of man, the most successful and abundant mammals on earth today are rats and mice (Ali et al., 2018; Langton et al., 2001). They would not have been enjoying this without man's inadvertent help. Rats and mice are considered as commensal for the fact that these animals live at man's expenses, invade his home, eat his food and destroy his commodities. Presence of rats and mice in a human living facility creates a nuisance and physiological discomfort. Along with this, they may also be associated with certain rat-borne infections, allergies and diseases which is due to direct contact with rats or their excreta (Bonnefoy et al., 2008). They are also capable of transmitting diseases to man who thus drives no benefits from this relationship (Boque, 1992). The transmission of human leptospirosis, plague, salmonellosis, Lassa fever, Hantavirus, endoparasites and ectoparasites associated with rats among the urban slum

Rafique, A, M.S. Mahmood, R.Z. Abbas, A. Ashraf, S. Nasir, F. Jabeen, T. Sultana, S. Sultana, G. Abbas, M. Luqman, A. Abbas and S.F.A. Albaayit. 2021. Analysis of different factors contributing the rodent infestations in urban areas in Faisalabad, Pakistan. Pak. J. Agri. Sci. 58:1197-1203.

[Received 29 Jan 2020; Accepted 30 July 2020; Published (online) 21 Sep 2021] 
residents of different countries (Costa et al.,2014; Langton et al., 2001).

The ever-increasing demand for energy, food, fiber and shelter has not only put sustained pressure on natural resources but has also blurred the environmental scene. The current rate of human urbanization, coupled with climate change and ineffective rat control has led to an increase in the risks associated with rodents (Head,2008). From 2000 to 2030, the global population is expected to grow by 2.2 billion, and the urban area will increase by 2.1 billion (Cohen, 2003; Bakr et al., 2019). By 2050, almost 70\% of all people will live in cities. These densely populated cities will inevitably spread the resources of wild animals especially rodents that support human dependence (Childs et al., 1998; Hulme-Beaman et al., 2016; Kong et al., 2019).

People are being attracted towards cities for employment due to the availability of labour work in a number of industries without caring for their residential facilities. This condition is more miserable in developing countries like Pakistan. Presently, this situation has aggravated to the lamentable standard of life teeming under the bridges, along railway lines and encroaching every patch of land available anywhere in and around cities (Riaz et al., 2019). These unauthorized settlements usually lack sewers, clean water supply, legal electricity connections, and suitable roads. Towering mounds of garbage, industrial waste and the city dumps are the characteristic features of the settlements. Such living conditions are ideal for many of the commensal animals especially rats and mice (Si et al., 2019). It seems a matter of fortune that any city in Pakistan has not come across any rodent disease outbreak. However, as the residents of Surat city of the neighbouring country, India faced an outbreak of pneumonic plague due to rats in 1994. That disease was the result of such an unhealthy and unhygienic condition of the city (Cunningham and Saigo, 1999).It also reflects the general trend seen in urban areas around the world, where the poorer conditions are prevailing; higher will be the level of rat infestation. Areas with infestation rates above $25 \%$ are at high risk of rodent borne diseases. The stored food and garbage in urban areas provide the best food and shelter to these commensals. Feed bins and corncribs waste food and spilled grains are primary food sources (Aboubakr et al., 2019). Improperly stored unhandled garbage adds those problems to the health of the urban environment and helps persistence of rat populations in cities and towns. Three species of worldwide distribution are the most important commensals: the Norway rat, brown rat or sewer rat (Rattus norvegicus), the roof rat (Rattus rattus) sometimes called the black rat or ship rat and house mouse (Mus musculus). All these species flourish well within Pakistan. With the focus on urban areas of Faisalabad, this study aimed to determine the relationship of socioeconomic factors and intensity of rodent problems in its various localities.

\section{MATERIALS AND METHODS}

Study area: Faisalabad is the city located in Punjab, Pakistan. It is located $31.42^{\circ}$ latitude and $73.08^{\circ}$ longitude and is situated at elevation 186 meters above sea level. Faisalabad is also called Manchester of Pakistan due to its textile importance, which attracts a lot of people from vicinities as labourer. There are also some 12000 house-hold industries which include as many as 60,000 power looms factories. Many squatters' settlements/kachi-abadies have emerged as results of manpower involved in factories. Three categories of housing systems were focused i.e. in squatters' settlements, departmental colonies and posh residences including bungalows in Faisalabad.

Table 1. Physical examination of residential structures in urban area in Faisalabad (Brook et al., 1990).

\begin{tabular}{|c|c|c|c|c|}
\hline $\begin{array}{l}\text { Commodity/ } \\
\text { Structure }\end{array}$ & $\begin{array}{l}\text { Criteria used } \\
\text { Excellent }\end{array}$ & Good & Fair & Poor \\
\hline Grain quality & $\begin{array}{l}\text { Grains without } \\
\text { damage, no } \\
\text { impurities and no } \\
\text { broken grains }\end{array}$ & $\begin{array}{l}\text { Grains without damage } \\
\text { mixed with some small } \\
\text { amount of impurities, a } \\
\text { few broken grains. }\end{array}$ & $\begin{array}{l}\text { Slight damage, mixed with } \\
\text { impurities, obvious broken } \\
\text { grains mixed with some } \\
\text { rodent fecal droppings }\end{array}$ & $\begin{array}{l}\text { Obvious damage grain mixed with } \\
\text { impurities many broken grains and } \\
\text { fecal dropping }\end{array}$ \\
\hline Structure & & No obvious & Few & Many obvious \\
\hline Conditions & & Defects visible & $\begin{array}{l}\text { Defects visible ,may or may } \\
\text { not need repair }\end{array}$ & Defects and need repair \\
\hline $\begin{array}{l}\text { Rodents } \\
\text { abundance } \\
\text { vs } \\
\text { Environment } \\
\text { Structural defects }\end{array}$ & & $\begin{array}{l}1-10 \text { rats and mice per } \\
\text { structure ,no fecal } \\
\text { droppings and no } \\
\text { evidence of damage }\end{array}$ & $\begin{array}{l}10 \text { or more rats and mice per } \\
\text { structure, fecal droppings in } \\
\text { spilled grains }\end{array}$ & $\begin{array}{l}50 \text { or more rats and mice per structure, } \\
\text { fresh fecal droppings and tracks were } \\
\text { common, gnawing, one or more rats } \\
\text { or mice seen at day light }\end{array}$ \\
\hline Doors & \multicolumn{4}{|c|}{$\begin{array}{l}\text { Marked as defective if they are allowed a gap large enough for rodents to enter when closed. This was usually due } \\
\text { doors bent out of shapes, broken hinges or actual doors missing. }\end{array}$} \\
\hline Floor & \multicolumn{4}{|c|}{ Marked as defective if they were cracked } \\
\hline Windows & \multicolumn{4}{|c|}{ Marked as defective if glasses or screens were broken, torn or missing } \\
\hline Walls & \multicolumn{4}{|c|}{ Marked as defective if plaster or concrete had broken away from surface or had holes or cracked } \\
\hline Roofs & \multicolumn{4}{|c|}{ Marked as defective if there were cracks or leaks. } \\
\hline
\end{tabular}


Study design: A questionnaire was used to evaluate the association between household environmental conditions and rodent infestations by conducting the interviews with household persons and obtaining the operational and structural details of various structures to be sampled for rodent population estimation. A physical examination of structures, looking for structural defects, grain quality, structure quality and rat population awareness, evidence of commensal rats and mice were also employed.

Rodent population estimates: Rodent populations were studied and estimated by the techniques accepted both biologically and statistically. A complete trapping gives the actual population present in a given locality. The criteria used to know the degree of infestation from the visible evidences, such as fecal droppings, runways, structure and bag damages, grain quality structure conditions, structural defects and severity of commensal rats and mice infestation was followed by the given standards (Table 1).

A total of 720 structures (240 each) were selected from these three housing systems i.e. in squatters' settlements, departmental colonies and posh residences including bungalows in Faisalabad. Snap and live trapping of commensal rats and mice (Rattus rattus, Rattus norvegicus, Mus musculus) was carried out fortnightly from November 2017 to October 2018 suspecting the rats and mice population as variable as different structured housing systems. The numbers and size of rodents from various structures that were actually trapped in each structure are given in Table 1.

The trapping was carried out using metallic snaps rat traps $(17 \times 9.5 \mathrm{~cm})$, for mouse $(11.5 \times 4.5 \mathrm{~cm})$ and live trap (cages) purchased from the local market. Various structures were served with 18 traps and 2 live traps (cages) during each night of the given trapping season. A total of 100 traps were served each night the rat and mouse traps were set in 1:1 in each structure. The bait used was wheat bread soaked with homemade butter. The traps were set at about dusk and checked on the next morning. Each specimen caught in the trap was tagged with a field number before it was brought in the laboratory. Each trapping period lasted for three successive nights in a week. Before and following each trapping session, inked trapping tiles were placed at an appropriate place in each of structure taking into consideration the place of harborage, tell-tale signs of rodents. In all, 100 tracking tiles were placed each night. Traps and tiles were checked for the presence of footprints.

The removal data were used to estimate the size of population of rats per structure. Two methods, i.e. change-in-ratio (CIR) (Davis and Winstead, 1980) and Regression of daily capture on cumulative captures (RR) (Blower et al., 1981) were employed to estimate the original population. In CIR trappings and using the unknown number of animals removed was calculated by the following formula:

$$
\mathrm{P}_{1}=\left(\mathrm{T}_{1 \times} \mathrm{n}\right) /\left(\mathrm{T}_{1-} \mathrm{T}_{2}\right)
$$

Where $P_{1}$ is the estimated original population, $n$ is the number of animals removed, $\mathrm{T}_{1}$ is the proportion of the little score positive before trapping and $\mathrm{T}_{2} \mathrm{is}$ the proportion of tiles score positive after trapping.

In the regression of daily captures on cumulative captures (removal regression (RR method) daily declines in the capture were plotted against cumulative total captures. A regression line was fitted to the plotted points. The point of intercept of the regression line with the $\mathrm{X}$ - axis gave the estimated population.

Collection of demographics and socioeconomic data: These data were supplemented by information collected through interviews of people of residential structures about construction and maintenance from Faisalabad development authority (FDA). The demographic, socio-economic and physical surveys of recognized residential areas were conducted. These surveys included household size, type of family, number of family members per structure, monthly income of residents, covered area, number of rooms in a house, in housing facility and land uses (residential area, parks, schools, dispensaries etc.). A list of recognizes squatters' settlements/kachi-abadies was obtained from Directorate General of FDA. This list recognized squatters' settlements/kachi-abadies based on agreed criteria of 40 houses and information was provided by the FDA.

\section{RESULTS}

\section{Type of housing facility and rat infestations}

Houses in squatters' settlements: Squatter settlement orkachi-abadis (locally named) could be defined as a residential area which had developed without legal claim to the land. Their illegal or semi-legal status, infrastructures and services were usually inadequate. According to our results, these were the encroached inhabitations of cities and rural area where housing and living conditions were appallingly lacking.

An area of a house in kachi- abadies was ranged from 48 to $60 \mathrm{~m}^{2}$. Usually the house was made of mud and bricks thatched roof; broken windows and doors; mud floor. Leakage in roof and holes in walls were common. Sewerage system, cleanliness and clean drinking water supply were absent. Towering mounds of garbage and waste materials food were common. Average family size was large i.e. 12 members per family and low income people living there. Kitchen refuse or flour was in bins and bags. Fresh fecal droppings, tracks were conjoint. Damage to flour bags, the gnawing of paper, bread due to rats and mice were communal. Goods were in poor condition, the presence of more than 50 rats indicates a high infestation of rodents. The one year sampled contained a total of 814 specimens comprising of 560 specimens of $M$. musculus, 184 of $R$. rattus and 70 specimens of S. murinus (Table. 2). 
Table 2. Demographic and socio-economic data of urban residential area and rodent infestations.

\begin{tabular}{|c|c|c|c|c|c|c|c|c|c|c|c|c|}
\hline Residences & class & $\begin{array}{c}\text { Average } \\
\text { family } \\
\text { size }\end{array}$ & $\begin{array}{l}\text { Type of } \\
\text { family }\end{array}$ & $\begin{array}{c}\text { Annual } \\
\text { income } \\
\text { Rs. }\end{array}$ & $\begin{array}{c}\text { Per } \\
\text { capita } \\
\text { income }\end{array}$ & $\begin{array}{c}\text { Average } \\
\text { covered } \\
\text { area } \\
\text { (Marlas) }\end{array}$ & $\begin{array}{c}\text { No of } \\
\text { rooms per } \\
\text { structure }\end{array}$ & $\begin{array}{c}\text { Total } \\
\text { structure }\end{array}$ & $\begin{array}{l}\text { Total } \\
\text { Area }\end{array}$ & $\begin{array}{c}\text { Availability of } \\
\text { utilities* }\end{array}$ & $\begin{array}{c}\text { Available } \\
\text { communities } \\
\text { Facilities\# }\end{array}$ & $\begin{array}{c}\text { Total } \\
\text { capture } \\
\text { of } \\
\text { rodents }\end{array}$ \\
\hline $\begin{array}{l}\text { Houses in } \\
\text { Kachi-abadies }\end{array}$ & $\begin{array}{c}\text { Lower } \\
\text { class }\end{array}$ & 12 & $\begin{array}{c}90 \% \\
\text { Joint } \\
\text { family }\end{array}$ & 54000 & 4500 & 1.8 & $1-2$ rooms & 73 & $\begin{array}{c}60000 \\
\mathrm{~m}^{2}\end{array}$ & Almost nil & $\begin{array}{l}\text { Not available } \\
\text { except in } \\
\text { some cases }\end{array}$ & 814 \\
\hline $\begin{array}{l}\text { Houses in } \\
\text { Departmental } \\
\text { colonies }\end{array}$ & $\begin{array}{l}\text { Lower } \\
\text { middle } \\
\text { class }\end{array}$ & 5 & $\begin{array}{c}30 \% \\
\text { Joint } \\
\text { family }\end{array}$ & 240000 & 48000 & 7.5 & $\begin{array}{c}6-10 \\
\text { rooms }\end{array}$ & 10 & $\begin{array}{c}300000 \\
\mathrm{~m}^{2}\end{array}$ & $\begin{array}{l}\text { Sufficiently } \\
\text { present }\end{array}$ & Present & 210 \\
\hline $\begin{array}{l}\text { Posh } \\
\text { residences and } \\
\text { bungalows }\end{array}$ & $\begin{array}{l}\text { Middle } \\
\text { class }\end{array}$ & 4.8 & $\begin{array}{c}20 \% \\
\text { Joint } \\
\text { family }\end{array}$ & 4800000 & 400000 & 25 & $\begin{array}{l}10-15 \\
\text { rooms }\end{array}$ & 15 & $\begin{array}{c}1200000 \\
\mathrm{~m}^{2}\end{array}$ & Excellent & Present & 30 \\
\hline
\end{tabular}

*Availability of utilities (water supply, Sewerage, Drainage, Solid waste Management, Garbage disposal, Street pavement electricity,

Gas and telephone. \#Available communities Facilities (primary school, Dispensary Parts, Shopping facilities, Mosque, Post office,

Community hall and bank)

Houses in departmental colonies: The houses in departmental colonies were administered and managed by the concerned Govt. agencies, such as WAPDA and SNGPL. Area of a house was ranged from 375 to $400 \mathrm{~m}^{2}$.Average family size was five members. Houses were made of cement and tiles, i.e. roofs, walls and floor were in good condition. Sewerage and cleanliness systems were in good condition. Wheat was stored in tin drums. Food was properly stored in containers. Cereals, kitchen refuse, kitchen waste were well managed in bins. Windows and doors were in good condition and apparently proofed from rodents. However, some fecal droppings and few mice foot prints were observed indicating low infestation of rodents. The one-year sample contained a total of 210 specimens comprising 129 specimens of M.musculus 71 of $R$. rattus and 10 specimens of S.murinus (Table. 2).

Posh residence and bungalows: The area of bungalows ranged from 500 to $675 \mathrm{~m}^{2}$.Floor walls and roof were made of cement. Drainage and sewerage systems were very well maintained. Proper food storage and standard of life were extraordinarily high. Doors and windows were thoroughly screened and found in good condition. Food available for rodents was only kitchen refuse but that was also correctly managed for disposal. Wheat grain was stored in drums. There was no sign of fecal droppings or gnawing. The structures in posh residences were found rats free. One year sampled comprised only of 30 specimens of M. musculus (Table. 2).

Socio-economic factors and rodent infestations: People living in Faisalabad, Pakistan were showing four different classes depending upon per capita income and other income resources. These can be classified into the upper-class, middle class, lower middle class and lower-classlevels (Table. 2).

Houses in squatters' settlements: Slums and squatter settlement have perforated in many of the other large cities. However, the poor quality of these typical shelters persisted mainly because of the insecurity of the land tenure.

The houses in kachi-abadies comprised of one to two rooms only, the average household size was $11 \mathrm{~m}^{2}$ (Table.2). These all represented a very congested and overcrowding situation. The percentage of joint families was as high as $90 \%$. The environmental situation of kachi-abadies was very dismal. The economic situation was awful as the average monthly income was less than Rs. 4500 (\$32) per house whereas the saving was nil. The size of the household depicted the level of overcrowding in kachi-abadies. The availability of utilities such as water supply, sewerage, drainage of the area, solid waste management, garbage disposal and street pavement is necessary for healthful living, and these were found absent in these human dwellings. Instead heaps of garbage were shared there was no proper cleanliness. These were areas of multiple deprivation and social exclusion, suffering from a combination of linked problems such as unemployment, poor housing, bad health and poor-quality environment. These were the highly populated areas of the city. The average covered area of one of the kachi-abadies was $60,000 \mathrm{~m}^{2}$, which had a population of more than 120,000 peoples indicating overcrowding of these city structures. There was a strong correlation between the level of location, sewerage, garbage, and disposal systems and rodents population size. Food disposal, refuse and damaged goods were located close to the food handling or food storage areas and were not sealed from rodents. According to the Pakistan Integrated Household Survey (PHIS) (Anonymous, 1998), almost 250,000 children under five years of age die due to lack of environmental sanitation and poor hygienic conditions of their residing places. Health facilities were absent or insufficiently available. The study of economic aspects of the inhabitants of kachi-abadies was necessary for the assessment of rodent problems. The monthly income of the household determined the level of poverty. The spatial distribution of income affected the housing characteristics in the settlements and type of structures. The rodent density was much high in kachiabadies. All the above-mentioned factors determined the density of the population of rats and mice. Problems in the surrounding areas, including the type of building litter and rubbish had a high level of co co-correlation with the density of rodent populations (Table.2). 
Houses in departmental colonies: The houses in departmental colonies were constructed by government or companies for residential purpose of their employees and their families. There were ten departmental colonies under study in Faisalabad city. There were 6-10 rooms in most of the houses; the percentage of the joint family system was $30 \%$ showing satisfactory environmental hygiene. The physical outlook and individual houses were found suitable. The monthly household income was Rs.20000 (\$140). Availability of the utilities such as sewerage drainages of these areas, solid waste management and garbage disposal were assured. Social and environmental aspects were better. Food disposal, refuse and damage good were somewhat sealed from rodents. By and large the environment was healthy. The covered area was more than the open space and proofed from rodents. The number of persons per room was less due to greater covered area of each house.

The living standard was much better than those of kachiabadies, ageing had effects on the house hold structures which were suspected to favour rats and mice infestations in these settlements, yet there were relatively good sanitary conditions showing better hygienic consciousness of the residents. There was less access of rodents to foods and other such commodities. The common points of accession into buildings for the rodents were poorly fitted or aged doors and windows where the unnecessary holes 'sere not adequately scaled (Table. 2)

Posh residences and bungalows: The bungalows were the residences of an economically sound class of the society. These human habitations were socially, economically and environmentally well developed (Table 2). There were fifteen colonies of posh residences and bungalows in Faisalabad city. There were 10-15 rooms in most of the bungalows. The average family size was small and the covered area was greater. The house presented the best quality of construction. The percentage of joint family system was very low (20\%). The economic status of posh residents was high as average monthly income was about Rs. 100,000-400,000 (\$704\$2816). These habitations were lavishly maintained to keep up the wealthy look and environmental conditions. The availability of utilities, i.e. water supply, sewerage, drainage of the area was very well maintained (Table 2). All commodities (edible or otherwise) were adequately well protected and stored, and the wastes did not provide harborage or food to rodents as these were disposed properly. Garbage and refuse were placed in covered metallic containers. The doors and windows were the rare points of access into buildings for rodent. Unnecessary holes were sealed with cement. Nearly all the buildings were made proofed for rodents and other small animals. This was the obvious reason for scarcity or absences of rodents in these human habitations. Only thirty specimens of mice could be captured from here (Table. 2). Economic development is very much vital for the development of society; the physical and social improvements and general cleanliness play an important role in reducing rodent populations. This proved true in the present study.

\section{DISCUSSION}

Higher levels of rodents infestations especially the abundanceof rats and mice, is a frequent feature within urban and peri-urban slum areas of in developing countries of the world like Pakistan and others. This study was conducted to investigate the possible association between the set of environmental and socio-economical factors and rat infestations in Faisalabad city of Pakistan. A similar study was performed in Madrid city and a district of Latina in Brazil. They assessed the possible interaction of urban rat infestations with environmental factors in the selected regions and found that Madrid city was the most problematic area regarding rat infestation (Tamayo-Uria et al., 2013). Commensal rats and mice live at human's expense, invade their home, eat their food and destroy their commodities, which derives no benefits from this relationship. Further, they have been associated with the variety of diseases, contaminations and destruction of structural damages helping environmental deterioration (Gratz, 1994; Lund, 1994). For the assessment of commensal rats and mice infestations, the houses in kachi-abadies, houses in departmental colonies and posh residences and bungalows were explored. Closely built lower middle-class houses in crowded localities, especially in the down town of Faisalabad were not sampled for rats and mice.

As far as the commensal rodent problem was concerned, it was frequently observed that most of the household occupants were not aware of the rats/mice infestation, which was proved right after trapping of the commensals. The ignorance of the problems might be more severe in the broader community of the country like Pakistan where literacy rate is far lower than that of an advanced country like the UK (with more than $90 \%$ literacy rate). In a study in England (Anonymous, 1999), it was found that over $30 \%$ cases of the occupants of the premises were of the infestation that existed. Langton et al. (2001) concluded that infestation by commensal rodents had two general forms. Firstly, less satisfactory unfit human habitations situated in areas with multiple problems including neglected or derelict buildings, commonly in urban areas with high densities of dwellings. Secondly, the older properties on large plots in rural areas with low density housing reflected reservoir populations of commensal rodents present in agricultural habitats. Alexander (1998), reported that the cost of the cheapest acceptable shelter in big cities of developing countries like Pakistan, India, Bangladesh and Indonesia was beyond the reach of its large proportion i.e. $75 \%$ of their population. The governments of these countries were unable to provide subsidies to these low-income people on account of their limited resources. Therefore, the low-income people 
tried to set up its shelter for the misery on them. The quality of housing and the availability of services were of secondary importance. That was why they accepted whatever accommodation was available of that which could be quickly and easily erected with low cost informal building materials because they had to settle somewhere. So, they pitched their "Jhuggis", if not their tents, whatever space they could find. Thus, the squatter settlements/kachi abadies were born. Other probable factors favouring such inhabitations are; Industrialization and more significant job opportunities in urban areas elicit migration, whether in community, interstate or international is usually from the areas of higher cost of survivorships to low cost of survivorships leading to quality of life opportunities. The squatter settlements are included in the spectrum as a response of the unavailability of basic needs of food and fabric at their rural home place. There, the amenities of life remain inaccessible in these inhabitations. Lack of education and non-awareness of rodent problems and lack of health consciousness, unplanned houses and lack of efficient collection and proper disposal of refuse are probable factors creating an environment providing suitable shelters and breeding grounds for the commensal rodents in the human squatter dwellings. So did the present study reveals that the kachi-abadies dwellings have been proved as reservoirs of rodent infestations to other structures of the city. Among the city structures human habitations (especially kachi-abadies) were heavily infested. Pakistan has four provinces (Punjab, Sindh, KPK and Baluchistan). Punjab province is the largest one having 55.6 percent of the total population of Pakistan (Anonymous, 1998). There are more than 900 kachi-abadies in Punjab (Anonymous, 1987). Accordingly, there are 73 recognized kachi-abadies in Faisalabad city (The second largest city of Punjab). Increased age and density of housing, and decreased distance to vegetated areas, markets and cat feeding stations were factors associated with an increased risk of rat infestations as studied by Tamayo-Uria et al. (2014). Our samples collected from the urban area, which present the same conclusions in agreement with Tamayo-Uria et al. (2014).

Demographic assessments show that a significantly larger, i.e. $55 \%$ portion of the total population is living below the poverty line. Out of the rest of $45 \%$, a $23 \%$ population is having middle-order amenities striving for optimal access to the resources. Less than $1 / 4^{\text {th }}(22 \%)$ people of Punjab in Pakistan are enjoying all the resources unjustifiably to the wasteful and luxurious extent, depriving the basic needs of a big folk. The disparity between haves and have-nots seems to increase with the unstable political and economic status of the country. Lack of vision of policy makers and ad-hocism has aggravated the miseries of the poor's, diseased and undernourished health to the small rich segment of the society. Kachi-abadies showed the hotspot areas of rodent infestation in urban areas.
Conclusion: The present manuscript concludes that the major socioeconomic factors contributing to the higher rodent infestations are low grade residences with inadequate or no building maintenance measures and higher housing densities along with heterogenous breeding sites. The higher densities of rats and mice may pose a serious disease threats to human populations as they are carriers of number of pathogens. The findings of the present study provide the specific features of rats and mice population concerned with human residences and may help to formulate controlling strategies against these culprits.

\section{REFERENCES}

Aboubakr M., S.S. Ibrahim, A.M. Said, F. Elgendey and A. Anis. 2019. Neuroprotective effects of clove oil in acrylamide induced neurotoxicity in rats. Pak. Vet. J.39:111-115.

Alexander, E.R. 1998. Informal settlement in Latin America and its policy implications. In: Patton, C.V. (ed). p:125146.

Ali, M. J., M. A. Abd Alfatlawi and A. C. Karawan, 2018. Molecular Identification And Phylogenetic-Tree Analysis Of Moniezia Species From Sheep In AlDiwaniyah City. Bull. Iraq Nat. Hist. Mus. 15:131-137.

Anonymous, 1987. Shelter for Homless Pakistan Canvas. Environment and Urban affairs Division, Govt. of Pakistan.

Anonymous, 1998. Population and housing census of Pakistan. Pop. Census. Organization Statistics Division, Islamabad, Pakistan. pp:3-23.

Bakr, A.F., S.S. Abdelgayed, O.S. EL-Tawil and A.M. Bakeer. 2019. Assessment of ginger extract and ginger nanoparticles protective activity against acetaminopheninduced hepatotoxicity and nephrotoxicity in rats. Pak. Vet. J. 39:479-486.

Blower, M.G., L.M. Cook, and J.A. Bishop. 1981. Estimation the size of animal populations. George Allen and Unwin Ltd London.

Bonnefoy, X., H. Kampen and K. Sweeney. 2008. Public health significance of urban pests. World Health Organization, Copenhagen Breiman L, Friedman JH (1985) Estimating optimal transformations for multiple regression and correlation. J. Am. Statist. Assoc. 80:580598.

Boque, M.M. 1992. Towards integrated commodity. Section 7: Biology and control of other storage pests. University of California, Davis. pp:1-14.

Childs, J.E., S.L. McLafferty, R. Sadek, G.L. Miller, A.S. Khan, E.R. Dupree, R. Advani and G.E. Glass. 1998. Epidemiology of rodent bites and prediction of rat infestation in New York City. Am. J. Epidemiol. 148:7887. 
Cohen, J.E. 2003. Human Population: The Next Half Century. Science. 302:1172-5.

Costa F, G.S. Ribeiro, R.D.M. Felzemburgh, N. Santos, R.B. Reis, A.C. Santos, D.B.M. Fraga, W.N. Araujo, C. Santana, J.E. Childs, M.G. Reis and A.I. Ko. 2014. Influence of household rat infestation on leptospira transmission in the urban slum environment. PLoS Negl Tro.p Dis. 8:e3338.

Cunningham, W.P. and B.W. Saigo. 1999. Environmental Science McGraw-Hill. North America. pp:537-555.

Davis, D.E. and R.L. Winstead. 1980. Estimating the number of wildlife populations. In: Wildlife Mnagement Techniques (Schemnitz, S. and L. Toschik) eds. The Wildlife Society, Washington, D.C.

Gratz N.G. 1994. Rodents are carriers of disease. Rodent Pests and their control (eds A.P. Buckle \& R.H. Smith), CAB Int., Wallingford, UK. Pp: 85-108.

Head B.W. 2008. Wicked Problems in Public Policy. Public Policy. 3:101-18.

Hulme-Beaman A., K. Dobney, T. Cucchi and J.B. Searl. 2016. An ecological and evolutionary framework for commensalism in anthropogenic environments. Trends Ecol. Evol. 31:633-45.

Kong L.J., T.H. Hsu, H.C. Wang, K.S. Chen and W.M. Lee. 2019. Effects of estradiol alone and estradiol combined with trivalent chromium on bone metabolism in ovariohysterectomized rats. Pak. Vet. J. 39:278-284.

Langton S.D., D.P. Cowan and A.N. Meyer. 2001. The occurrence of commensal rodents in dwellings as revealed by the 1996 English House Condition Survey. J. App. Ecol.38:699-709.

Lund M. 1994. Commensal rodents. Rodent pests and their control (eds A.P. Buckle and R.H. SMITH). CAB International, Wallingford, UK. Pp: 23-43.

Riaz A., S. Noureen, M.F. Qamar, I. Liaqat, M. Arshad and N. Arshad. 2019. Characterization of bacteriocin like inhibitory substances from Enterococcus ratti MF183967. Pak. Vet. J. 39:1-6.

Si W., R. Zhu, T. Kang, S. Ji, Z. Yao, J. Ye, W. Tian, Y. Liu and F. Fang. 2019. Effect of active immunization using gonadotropin-releasing hormone 2-multiple antigen peptide with different adjuvants on the reproductive functions of male rats. Pak. Vet. J. 39:205-210.

Tamayo-Uria I., J.M. Mahiques and L.M. Gras. 2013. Temporal distribution and weather correlates of Norway rat (Rattus norvegicus) infestations in the city of Madrid, Spain. Eco. Health. 10:137-144.

Tamayo-Uria I., J.M. Mahiques, F. Escobar and L.M. Gras. 2014. Risk factors and spatial distribution of urban rat infestations. J. Pest Sci. 87:107-115. 